\title{
Historiographic Metafiction and the Metaphysical Detective in Roberto Bolaño's Amulet
}

\author{
Rhys William Tyers \\ Ph.D. student, College of Arts, Social Sciences and Commerce, \\ La Trobe University, Melbourne, Australia \\ rhys.tyers@gmail.com
}

\begin{abstract}
Roberto Bolaño's Amulet explores the writing of history as an attempt to construct a narrative from a multitude of unreliable and conflicting sources. As a result, any attempt at historiography is also plagued by the problems of representation found in literature. More particularly, not unlike detective fiction, history is concerned with identifying the inspirations and actions of its players and with revealing the truth about an episode or series of episodes, using historical information, all of which may or may not be reliable. By examining the relationship between the historical and the fictional in Amulet this paper will discuss Bolaño's use of the tropes of metaphysical detective fiction and how they help foreground the difficulties posed by historical facts by reinventing them in fiction. This will, in turn, highlight the intersection between detective fiction and historiographic metafiction and how by combining these two genres writers can reimagine historical contexts and find new meanings and significance.
\end{abstract}

\section{Keywords}

metaphysical detective - Roberto Bolaño - historiographic metafiction - narrative and memory

"I think fiction rescues history from its confusions. It can do this in the somewhat superficial way of filling-in blank spaces. But it also can operate in a deeper way: providing the balance and rhythm we don't experience in our daily lives, in our real lives. So the novel which is within history can also operate 
outside it - correcting, clearing up and, perhaps most important of all, finding rhythms and symmetries that we simply don't encounter elsewhere" (DeLillo as cited in Block and Norris 2017).

The writing of history is an attempt to construct a narrative from a multitude of unreliable and conflicting sources. As a result, any attempt at historiography is also plagued by the problems of representation found in literature. More particularly, not unlike detective fiction, history is concerned with identifying the inspirations and actions of its players and with revealing the truth about an episode or series of episodes, using historical information, all of which may or may not be reliable.

Amulet, a novel by Roberto Bolaño (2010), is a first-person account of Auxilio Lacouture (a genuine historical figure), a Uruguayan woman living in Mexico, who spent a miserable two weeks hiding in a bathroom of the Department of Philosophy and Literature during the Mexican army's occupation of the National Autonomous University (UNAM) between 18th and 3oth September 1968. Even though the novel has a specific historical event as its backdrop it has no conventional plot since the narrator Auxilio becomes quite sick, starts to hallucinate and has an unreliable memory.

Bolaño's novel, then, is concerned with both history and literature as outlined above. It revisits an historical event but it does so through the subjective and interpretative medium of fiction. Hutcheon's (1988) term 'historiographic metafiction' describes texts such as Roberto Bolaño's Amulet, which use 'imaginative reconstruction' to think through 'the problems of how we... have knowledge of the past.' Before postmodern subjectivity affected our relationship with historical writing, history was considered to be an accurate representation of the past and literary texts were viewed as 'outside' history; however, both kinds of writing are, according to Hutcheon $(1988,3)$, "linguistic constructs, highly conventionalized in their narrative forms... they appear to be equally intertextual".

The postmodern relationship between fiction and history is a complex one of interaction and mutual implication and, as a consequence, historiographic metafiction works to situate itself within historical discourse without surrendering its autonomy as fiction. In fact, the intertexts of history and fiction take on a parallel (though not equal) status in the parodic reworking of the textual past of both the "world" and literature.

One of the effects of postmodern fiction and its treatment of the past is how it is able to prevent history 'from being conclusive and teleological' (Hutcheon 1988, 110). This forces the event to remain 'unconsumed' and the reader to question the established truths of history and to realise that the past is as unstable and open to interpretation as any fiction. Thus, historiographic 
metafiction raises questions about our relationship with historical knowledge and forces history to share with fiction its claim to truth by demonstrating that both are 'discourses, human constructs' (Hutcheon 1988, 93). These 'postmodern historiographers', one of whom is Bolaño, think of history as a narrative or a cultural conceit.

For Bolaño to interrogate such a wide field, it was important to develop his own genre or, at the very least, have complete freedom to interpret and render the text (Amulet) as he saw fit: "Indeed what seems unique to Bolaño's poetics is that, to a great extent, this figure (Auxilio) represents everyone, author and reader alike, all embarked on a perennially multifaceted search with no end or solution in sight" (Pastén 2013, 22). Another clear link between the history that Bolaño is 'creating' and the detective is the impossibility of ever really solving the crime. In many of Bolaño's works “...there is even a certain sense of the absurd regarding the crime as if the crime lacked a cause" (Pastén 2013, 23). The cause or crime that the protagonist/detective is pursuing remains elusive and may never be clearly articulated.

A brooding existential dread simmers beneath the surface of the novel that is "produced chiefly by historical circumstances" (Pastén 2013, 23). This feeling of dread is amplified by the strikingly powerful presence of the megalopolis of Mexico City, which is depicted as a postmodern space: hostile and depersonalized (Pastén 2013, 23).

By examining the relationship between the historical and the fictional in Amulet this essay will discuss Bolaño's use of the tropes of metaphysical detective fiction and how they help foreground the difficulties posed by historical facts by reinventing them in fiction.

Critics who attack postmodernism for being what they see as ahistorical (as do Eagleton in The Illusions of Postmodernism (1996), Jameson in Postmodernism (1991), or, The Cultural Logic of Late Capitalism (1991), and Newman in The Postmodern Aura (1985)), seem to be working from a very rigid definition of what constitutes "postmodern", for surely one could argue that historiographic metafiction, like postmodernist architecture and painting, is overtly and resolutely historical - its ironic approach problematizes and thereby acknowledges that history is not the transparent record of any sure "truth" (Hutcheon 1988, 5). Thus, historiographic metafiction actually allows the reader to investigate history albeit in an ironic way. 
Bolaño opens up historical dialogue through metafictional techniques. This is exemplified by the fact that the narrator often intrudes into the story by stopping the narrative to comment on the process of the writing: "I thought, because I wrote, I endured. I thought, because I destroyed what I had written, they will find me, they will hit me, they will rape me, they will kill me. I thought, the two things are connected, writing and destroying, hiding and being found" (as cited in Marostain 2009, 54). These reflections on the act of writing highlight the constructed nature of narrative and, by extension, established history and historical narratives.

By drawing the reader's attention to and questioning the assumptions and conventions of narrative and how it transforms reality, Bolaño repositions the historical event that he is describing. His narrator states, "Now I believe, if you'll excuse a brief digression, that life is full of enigmas, minimal events that, at the slightest touch or glance, set off chains of consequences, which, viewed through the prism of time, invariably inspire astonishment or fear" (Bolaño 2010, 23). Forgotten voices are celebrated and the minor narratives of history are given the same weight as established history. Another metafictional technique that is employed is the rejection of conventional plot structure, which makes the novel sometimes difficult to read. The text also abounds with literary allusions both established and well known and obscure and fictional, which adds to this disorientation and forces the reader to pay attention to history as an intertextual fabric of sources and stories.

\section{$2 \quad$ Amulet as Metaphysical Detective Fiction}

It is well documented that Roberto Bolaño had a strong interest in detective fiction as well as detection in general. In an interview with Monica Marostain, he stated:

I should like to have been a homicide detective much better than being a writer. I am absolutely sure of that. A string of homicides. I'd have been someone who could come back to the scene of the crime alone, by night, and not be afraid of ghosts. (Marostain 2009, 122)

Bolaño's fascination with detectives and detective fiction is evident in many of his novels from The Skating Rink (1993) and The Savage Detectives (2007) to 2666 Bolaño (2008) and Woes of the True Policeman (2012). However, the author's relationship with genre fiction is complex and shows a closer kinship 
to the definition of the metaphysical detective story as proposed by Merivale and Sweeney than the traditional detective narrative:

The metaphysical detective story is distinguished...by the profound questions that it raises about narrative, interpretation, subjectivity, the nature of reality, and the limits of knowledge (Merivale and Sweeney 1999, 1).

The metaphysical detective story is by its very nature difficult to define and has manifested itself in many ways and with many preoccupations. Some wellknown examples of the genre are Borges trilogy of stories Death and the Compass (1998a), The Garden of Forking Paths (1998b) and Ibn Hakkan Al-Bokhari-Dead in his Labyrinth (1998c) which parody and invert the detective stories of Edgar Allan Poe, namely The Murders in the Rue Morgue (1966a), The Purloined Letter (1966b) and The Mystery of Marie Roget (1966c). Other examples of the metaphysical detective genre are Umberto Eco's The Name of the Rose (2004), Paul Auster's The New York Trilogy (2006) and Thomas Pynchon's The Crying of Lot 49 (1966) just to name a few. However, due to the parodic nature of the genre and its endless uses, it is often considered as a facet of postmodern literature rather than a genre in its own right. Identified by Spanos and Holquist in the early 70 's as the form most likely to express the new literature that was gathering momentum in the 196os, it has now been accepted into popular culture. Spanos $(1972,154)$ considers the metaphysical detective story to be "the paradigmatic archetype of the postmodern literary imagination", while Holquist saw a new fiction that "instead of familiarity, gives strangeness (...) [i]nstead of reassuring, (...) disturbs" (Holquist 1971, 155). The tropes of the traditional detective narrative are the perfect smokescreen for the postmodern playfulness that hides behind the artifice of misleading genre conformity.

Although the tropes of detective fiction can be found in many of Bolaño's novels, it is Amulet that announces itself as a "story of murder, detection' (Bolaño 2010, 1). The 'terrible crime' that is mentioned in the opening paragraph of the novel is never specifically stated, which offers us the first departure from the traditional detective story. The crime in the hands of Bolaño could be memory or loss of memory or the interpretation of history itself. It could also be the faltering power of art, in this case poetry, and the disappearance of poets and their words.

Instead of the expected investigation we are faced with the same internal exploration as the protagonist, Auxilio Lacouture, engages with the past through reverie, starvation induced hallucination and fear. And as the narrative 
progresses, it becomes clear that Bolaño is not trying to merely offer an alternative history or to question established history. He is questioning the possibility of knowing anything. In Amulet he constructs a world full of impenetrable mystery in which the very possibility of truth is called into question and problematized. Vast networks of voices and conspiracies of silence converge in the text. Facts mix with fiction; historical events and historical figures collide with fictional events and characters. Gritty, almost hardboiled description is juxtaposed with flights of fantasy and stream of consciousness poetics. The story deals with history but a history of a very different kind.

The apparent detective of the story, Auxilio Lacouture, faces many of the characteristic themes of the metaphysical detective story such as the defeated sleuth, the city as labyrinth, mise-en-abyme, ambiguity, a plethora of evidence, the eerie meaningfulness or sheer meaninglessness of clues and evidence, the double or exchanged identity and the absence, falseness, circularity or self-defeating nature of any kind of closure to the investigation (Merivale \& Sweeney 1999, 8).

Merivale \& Sweeney define the genre as follows:

A metaphysical detective story is a text that parodies or subverts traditional detective-story conventions - such as narrative closure and the detective's role as a surrogate reader - with the intention, or at least the effect, of asking questions about mysteries of being and knowing which transcend the mere machinations of the mystery plot. Metaphysical detective stories often emphasise this transcendence, moreover, by becoming self-reflective (that is, by representing allegorically the text's own processes of composition) $(1999,2)$.

Holquist (1971, 170), as early as 1970, noted that: “...the metaphysical detective story...is not concerned to have a neat ending in which all the questions are answered, and can [therefore] be forgotten".

Thus, the metaphysical detective story is an ideal way of exploring history as it is not concerned with solutions and the answering of questions. It helps keep the events alive due to its ambiguity. The reader is forced to question the events in the light in which they are presented.

The historical context of the novel becomes clear but it is the treatment of the subject that disturbs the reader and alerts him/her to the significance of the story and why the author has chosen to present it in the way that he has.

The historian is often compared to the detective, finding clues and significance in a past event. The novelist, however, is more in line with the metaphysical detective as he explores a theme, a character or an event. 
"Bolaño successfully combines the two basic instincts of a novelist: He is attracted to historical events, and he desires to correct them, to point out the errors" (Marostain 2009, 54).

Although the political event that is at the heart of Amulet is never directly addressed, it is no secret that Bolaño's novel, as mentioned earlier, is set in Mexico City and the event that simmers in the background is the Mexican army's occupation of the National Autonomous University (U NAM) in 1968.

'Parodic reworking' is evident in Amulet. Auxilio Lacouture struggles to see the significance of the events that surround her. She is experiencing an historical event but it is her narrative, her way of telling the story, that helps us to examine history. Auxilio does not record the events of history; she lives through them and, in doing so, narrates how they have affected her and the people around her. We see the "complex [relationship] of interaction and mutual implication" at work in the novel by being witnesses to one woman's experience of history. We also see how narrative can shape experience and draw out connections and contradictions that a traditional historical account would try to avoid. As (DeLillo as cited in Block and Norris 2017) points out in the epigraph to this essay: 'fiction rescues history from its confusions'. We could add, however, that fiction, in a sense, also adds to this confusion.

History has been reduced by postmodern theory to a 'human construct'. It is what Jameson (1991) calls "a weakening of historicity" or "historical deafness" even, which he sees as one of the symptoms of our age: "Today, there is a return to the idea of a common discursive 'property' in the embedding of both literary and historical texts in fiction, but it is a return made problematic by overtly metafictional assertions of both history and literature as human constructs, indeed, as human illusions - necessary, but nonetheless illusory for all that" (Hutcheon 1988, 5). For postmodernists, there is no outside of ideology or textuality; indeed, postmodern theory questions any claim to "truth" outside of culture. Hutcheon and many writers of historiographic metafiction see this as a great opportunity as it offers a sense of the presence of the past but this is a past that can only be known from its texts, its traces - be they literary or historical. The past is reimagined but not merely to mock the unobtainable nature of knowledge and truth. As readers, we can see significance in past events; however, our understanding is problematised due to the fact that history, like fiction, is open to interpretation and play. That is not to say that history cannot teach us anything, on the contrary, through historiographic metafiction we are able to distil meaning from history and, hopefully, learn new lessons. 
In the postmodern novel, the conventions of both fiction and historiography are simultaneously used and abused, installed and subverted, asserted and denied. And the double (literary/historical) nature of this intertextual parody is one of the major means by which this paradoxical (and defining) nature of postmodernism is textually inscribed (Hutcheon 1988, 3).

Historiographic metafiction manages to satisfy a desire for "worldly" grounding while at the same time querying the very basis of the authority of that grounding. As David Lodge (2015, 239-240) has put it, postmodernism short-circuits the gap between text and world. Moreover, the historiographic metafictional novel allows us to investigate the past through the lens of postmodern subjectivity. This has the potential to challenge the reader's beliefs and assumptions about a particular historical event and its impact. The reader becomes the detective, but a metaphysical detective.

"When that past is the literary period we now seem to label as modernism, then what is both instated and then subverted is the notion of the work of art as a closed, self-sufficient, autonomous object deriving its unity from the formal interrelations of its parts. In its characteristic attempt to retain aesthetic autonomy while still returning the text to the "world," postmodernism both asserts and then undercuts this formalistic view" (Hutcheon 1988, 5-6).

The text, then, becomes a form of liberation. We are introduced to the relationship between works of art and other forms of culture and can see how history can play a role in that interaction. What historiographic metafiction challenges is both any naïve realist concept of representation and any equally naïve textualist or formalist assertions of the total separation of art from the world. The postmodern is self-consciously art "within the archive" (Foucault as cited in Lodge 2015, 92) and that archive is both historical and literary (Hutcheon $1988,6)$.

Historiographic metafiction provides us with a way of seeing the significance of art and its relationship to the world. By allowing different forms to interact, we are exposed to the possibilities of art, history and change. The tradition of history is opened up and discourse is allowed to grow and multiply. This is highlighted by Bolaño when he allows the narrator to drift in and out of coherence and to contradict herself:

...water, unlit by sun or moon, and time folded and unfolded itself like a dream. The year 1968 became the year 1964 and the year 196o became the year 1956. But it also became the years 1970 and 1973 and the years 
1975 and 1976. As if I had died and was viewing the years from an unaccustomed vantage point. I mean: I started thinking about my past as if I was thinking about my present, future, and past, all mixed together and dormant in the one tepid egg, the enormous egg of some inner bird (an archaeopteryx?) nestled on a bed of smoking rubble (Bolaño 2010, 31).

Historical events collide with flights of fantasy and history becomes the 'archive' that Foucault identifies. The author's metaphor of the egg here points to the potential of the event, to the future and to the significance of the event. The text, however, does not pretend to know the significance of the event. It presents itself as merely another narrative to draw upon; another archive to plunder. Bolaño, though, points out the significance of the events that are playing out in the background. "...the corridor was empty, nothing but faded shades of cream, and up the stairwell came a sound of shouting, a petrifying, history-making sound" (Bolaño 2010, 25). The protagonist experiences glimpses of the importance of the event but she remains isolated from it. There is little by way of reminiscence. The story alludes to its own potential significance but it refuses to interpret the significance of the event for the reader. Auxilio muses on the chaos that surrounds her but is powerless to tame or correct it.

However, when reminiscence does occur, we see the collision of facts and fiction and the confusion that ensues. Long (2010) and Marinescu (2013) have identified Amulet as an example of the genre of 'testimonio': a Latin American narrative genre that emerged in the wake of the Cuban Revolution as a political medium for recording, presenting and circulating the life stories and experiences of subaltern or socially marginalized subjects. The story evokes catharsis and a shared fear. However, again, this is just another genre that is plundered by the author; it is another genre that is used to inform the archive.

In the genre of the testimonio, history becomes a nightmare, when it intersects with personal memory. "Bathrooms were a nightmare for me, although since September 1968, I had grown accustomed to nightmares. You can get used to anything" (Bolaño 2010, 23). We do not get used to the intersection of history and literature but we cannot shy away from it. Similarly, historiographic metafiction destabilises history but it does not negate it. It invites us and destabilizes our understanding, but it does not negate established ideas of history and metanarratives.

Auxilio Lacouture has visions that point to the significance of the events she is experiencing but she also hints at the fragmented and fractured nature of the remembered past. The events are significant but their significance is found in their multiplicity; their myriad interpretations. 
...we're just taking you to attend the birth of History. But what's the hurry, doctor? I feel dizzy! And the doctors replied with the patter they use on the dying: The birth of History can't wait, and if we arrive late you won't see anything, only ruins and smoke, an empty landscape, and you'll be alone again forever even if you go out and get drunk with your poet friends every night. Well, let's get a move on, then, I said. The anesthesia was going to my head, overwhelming me as homesickness sometimes does, and I stopped asking questions (for a while). I fixed my gaze on the ceiling and all I could hear were the rubber wheels of the trolley trundling along and the muted cries of other patients, other victims of Pentothal (that's what I thought), and I even felt a pleasant, gentle warmth creeping up my long, frozen bones.

When we reached the operating room, the vision misted over, cracked, fell and shattered, and then the fragments were pulverized by a bolt of lightning, and a gust of wind blew the dust away to nowhere or spread it through Mexico City (Bolaño 2010, 152).

The porous boundaries of the text also represent the porous boundaries of the countries in South and Central America which are then emulated through the porous boundaries of genre. The unrest, crimes and people of Central and South America converge and collide in the context of the story which can be demonstrated its being set in Mexico, the protagonist being Uruguayan, the writer, Roberto Bolaño, is featured as a character (he is Chilean) and a host of other characters in the story coming from other places. They share a language, a past and a sense of injustice and we get a sense from reading Amulet that poets and other artists from Spanish speaking countries flocked to Mexico City, then the centre of the arts in the Latin world. The narrative itself and its 'play' with conventions is also mirrored by the character of Auxilio that is found in the novel and highlights the porous boundaries of Auxilio's consciousness and national borders

The genre boundaries, physical boundaries and historical boundaries all have a symbiotic relationship as they are in a state of 'perpetual flux' and are suited to each other due to the fact that they fuse "a kind of intertextuality that crosses generic boundaries as well as discursive boundaries" (Braham 2004, 135).

Bolaño's text, then, both adheres to and violates the codes of genre and historical discourse. The metaphysical detective genre "is inherently mobile and porous refusing at all costs to get trapped in the corset of any pre-established form" (Žižek 1992, 425). However, it can also be argued that it is a "rather paradoxical genre in the sense that it oscillates between an adherence to a certain 
code and a violation of the code" (Žižek 1992, 327). Thus, we can see a clearer connection between the metaphysical detective story and historiographic metafiction. Both have a starting place that can be considered as static, clear and governed by rules; however, in both fictions we find the opposing forces of established distinctions. Thus, both historical discourse and detective genre tropes are undermined.

The detective is used both symbolically and politically in Bolaño's work. Among the pages of Amulet one can find a search for personal identity but there is also a search for the political and the revolutionary: the long-lost socialist projects of Latin America. Another is the detective as defender of the immigrant in a foreign land, of the search for law in a world where such things are becoming increasingly ambiguous.

By using a detective motif the author is able to interrogate history but also to dehistoricise it by telescoping different historical points. This is achieved through historiographic metafiction and, although some may argue that this approach trivialises history (see Jameson (1991)) and its importance, it can also be argued that by doing this Bolaño has shared history to a wider audience and has added a wider significance. The history that Bolaño is presenting encourages the reader to take on the role of the detective. There are no neat endings or a narration of established events. We, as readers, are confused witnesses just as Auxilio Lacouture is a confused witness.

Bolaño's protohistory obscures both the detection and the crime. He is investigating history but it is not the history you think you know. We are faced with a history that refuses to stand still and be interrogated.

\section{4 Bolaño and Disorientation}

"Being a writer in this world is as dangerous as being a detective, walking through a graveyard, looking at ghosts" (Bolaño et al. 2009, 1).

One of the effects of reading Bolaño's novels, and this is the case with Amulet, is the disorientation that is created by the proliferation of literary references (both known and obscure).

Amulet is an example of cartography in the Deleuzian and Guattarian sense. To understand their cartography, it is important to explain how Deleuze and Guattari (1987) define the term. The best way to approach this understanding is to look at the difference between tracings and cartography.

In A Thousand Plateaus, Gilles Deleuze and Félix Guattari (1987) write that "literature is an assemblage". Their concept of rhizomatic writing positions heterogeneity, interconnectedness and multiple entryways into a text: 'Any point 
of a rhizome can be connected to anything other, and must be.' The rhizome is a network in a state of constant production and flux, 'defined solely by [...] all manner of becomings' (Deleuze and Guattari 1987, 5).

Maps themselves are like laboratories where experimentations on tracings are set in interaction. Thus, here the map is opposed to the structure; it can open itself in all its dimensions; it can also be ripped apart; it can be adapted to all kinds of assemblies (Guattari 2010, 172).

"This does not mean, nevertheless, that there is nothing to cling to in the text; rather, the challenge would seem to reside in knowing how to put the multiple parts of the puzzle together" (Pastén 2013, 28).

However, do these parts ever fit neatly together or, as Deleuze's rhizomatic cartography reminds us, are these parts merely more entry and exit points? Are they just pointing to themselves as assemblages, as infinite possibilities, as indefinable crimes, shadowy figures that never step into the light? History cannot be understood by applying the 'medical gaze' from the present. We discover the past through engagement, through reinvention, through plunder.

If Bolaño's texts are labyrinths, they are rhizomatic labyrinths. They offer potential instead of solutions, cartography instead of discernible traces. The reader identifies the crime and becomes the detective and, as with literature, it becomes an active participation.

Our experience of history is filtered through our own lives and the way we see the world. In the case of Amulet, the events of history are interrupted and disorientated through the reading experiences of the protagonist, Auxilio Lacouture. The narrator begins the novel by saying what it could have been from the perspective of another narrator: "This is going to be a horror story. A story of murder, detection and horror. But it won't appear to be, for the simple reason that I am the teller. Told by me, it won't seem like that" (Bolaño 2010, 1).

Auxilio's world is the world of literature and, more specifically, poetry. She is also, as her name suggests, our help or helper (Spanish: Auxilio = Help). She is guiding us through the narrative but her job is not an easy one. Every page is alive with allusions to literature, which leads to disorientation due to the sheer volume of references and the obscure nature of some of the poets that are discussed.

Bolaño's novel like many other stories that have played with the detective narrative leads us into a rhizomatic labyrinth. The best way to explain this is to consider Umberto Eco's three labyrinthine structures. The first labyrinth, the Greek variety, has one entry and one exit. The minotaur is easy to find, and Ariadne's thread will always lead you out of the maze. The second labyrinth, 
the Mannerist variety, is the maze of the traditional detective story. You can get lost. There are red herrings and dead ends but you will always be guided out of the labyrinth. Although it is not a straight line, there are exits and Ariadne will help you if you need it. The final labyrinth is the rhizome as created by Guattari and Deleuze (1987), which, as discussed above, has multiple entry and exit points. The protagonist is not trying to limit our understanding of the text or force her meaning on us. She understands and accepts the potential of the narrative and the infinite interpretations that will be found in the text:

"And when I heard those stories, those versions of my story, usually (if I wasn't drunk) I held my peace" (Bolaño 2010, 177).

Bolaño's work, according to David Millos, is an event where "both lucidity and obscurity take turns" (as cited in Marinescu 2013, 28). The final version of the text is never achieved. It remains unconsumed and invites multiple interpretations. The rhizomatic labyrinth and the minotaur comes in multiple guises and is undefeatable. Furthermore, the author is under no obligation to untangle the mystery; enunciating it suffices (as cited in Marinescu 2013, 28). The untangling is left to the reader, the true detective of the story. Reality is either elusive or distorted. Finally, we should try to find something among the lucidity and obscurity.

\section{Amulet and Memory}

The novel abounds with references to memory and hints at the relationship between history, literature, detection and forgetting.

As previously mentioned, Merivale and Sweeney (1999) define the metaphysical detective novel as a novel that is seeking more of an insight into the individual than the crime that has been committed and, in doing so, allows the reader to connect with the text on more of an ontological than epistemological level as is the case in the traditional detective story. As is the case with Amulet, the reader becomes the detective and this forces us, as we engage with the text, to question our own relationships with memory, history, literature, detection and forgetting.

Amulet, then, deals primarily with history and memory and the importance of keeping historical events and their significance alive and this is the message we can take away from the novel. Bolaño, moreover, resists the neat received history that one can find in textbooks for a history that draws inspiration from a variety of sources which include literature, memory, genre fiction, psychology and philosophy. He challenges us to engage with the archive and to question the story and the way he tells it. 
Bolaño highlights the false nature of memory and how it pertains to history by allowing the protagonist to contradict herself and struggle to remember key dates and events in her past:

I came to Mexico City 1967, or maybe it was 1965, or 1962. I've got no memory for dates anymore, or exactly where my wanderings took me; all I know is that I came to Mexico and never went back...Let me stretch time out like a plastic surgeon stretching the skin of a patient under anesthesia (Bolaño 2010, 2).

"Yes, it must have been 1965 (although I could be mistaken, it certainly wouldn't be the first time...)" (Bolaño 2010, 3).

The schizophrenic nature of memory (in the Deleuzian sense), forgetting and history are embodied in the character of Auxilio Lacouture. She investigates the event through her imperfect memory and through her own experiences and reading. As a result, her memories are infected with poetry, people and events that converge and collide and are difficult to rescue and define due to the interrelated nature of the instances.

"Maybe it was madness that impelled me to travel. It could have been madness. I used to say it was culture. Of course, culture sometimes is, or involves, a kind of madness" (Bolaño 2010, 3).

"All I knew for sure was that the vase was there, although it could also have been sitting on the ledge of an open window in Montevideo or on my father's desk, in Doctor Lacouture's old house, my father the doctor, who died so long ago I've almost forgotten him, and even now the pillars of oblivion are collapsing onto that house and desk" (Bolaño 2010, 10).

We can also see from the quotes above the difference in writing styles that are evident in the novel. The first exemplifies the concise sentences of the hardboiled detective story whereas the second quote breaks grammatical rules and resembles a stream of consciousness. Thus, the syntax exemplifies the content of the story and the thought process of the narrator.

Memory fades and changes and refuses to stay still and Auxilio Lacouture experiences this inertia when peering into her past. She is lost in a sea of broken images, but she still feels the need to make sense of them. Just like the metaphysical detective, she knows that defeat and non-solution await her but she still endures because she sees significance and meaning in what she remembers:

"The dark night of the soul advances through the streets of Mexico City sweeping all before it. And now it is rare to hear singing, where once everything was a song. The dust cloud reduces everything to dust" (Bolaño 2010, 13). 
Loss of memory or the refusal to remember destroys the past. We must historicise but we must also accept that many histories exist and that literature and history must work together to create the past: "Unbelievable. I was in the bathroom, in the lavatory on one of the floors of the faculty building, the fourth maybe, I'm not exactly sure" (Bolaño 2010, 22) and "Memory plays malicious tricks on me when the light of the waning moon creeps into the women's bathroom like a spider" (Bolaño 2010, 107).

Auxilio struggles with her memory throughout the narrative "...and once again I don't know if I'm in 1968 or 1974 or 1980, or gliding, finally, like the shadow of a sunken ship, toward the blessed year 2000, which I shall not live to see" (Bolaño 2010, 127).

However, in the throes of her confusion, she finds comfort in what she can remember: "Be that as it may, something is happening as time passes. I know that time and not, for example, space, is making something happen. Something that has happened before, although in a sense every time is the first time so experience counts for nothing, which is better in the end, because experience is generally a hoax" (Bolaño 2010, 127).

Amulet, then, is a meditation on the nature of memory and forgetting. Auxilio realises the significance of memory and history and experiences a sudden epiphany: "Then I woke up. I thought: I am the memory" (Bolaño 2010, 174). Although the investigation is flawed, it does shed light on the fact that history can be retrieved and re-examined.

The detective genre, first employed by Bolaño in his early poetic output, has always dealt with imaginary crimes, a search for meaning, marginalised space and people and, as Augusin Pastén $(2013,18)$ has pointed out, the use of this genre 'constitutes a kind of master trope of the author's total literary production'. And, although it would be misleading to label Bolaño, he returned to the tropes of the detective genre in his own way in almost all of the work he produced.

As mentioned above it is difficult to label Bolaño even though he consciously and explicitly draws from detective narratives to construct his narratives. Thus, a clear genre distinction and category cannot be applied to Bolaño's literary output. This becomes clear when we try to apply classical or hardboiled genre to the author's work. There are tropes from both genres, however, as one might expect and neither paradigm is followed faithfully. 
This breaking with genre conventions is an important and interesting trajectory to follow when considering Bolaño and his relationship with history. As mentioned earlier, Amulet deals with a specific historical event. The author, however, is not trying to faithfully reproduce history (if that is ever really possible). He is, instead, investigating minor narratives and voices and, in doing so, revitalises and democratises the idea that history is a defined and static time in the past that never changes and is only investigated through nostalgia and established and accepted documentation.

What Bolaño does take from the hardboiled genre is its distrust of institutions; he uses the investigation to question, to expose and dismantle the power structures he sees as controlling history and the historical narrative. As William J. Nicholas argues: "The hardboiled is a reaction against cultural crises spawned by the failure of modernity in the US at a time when individuals began to feel despair and alienation" (as cited in Lodge 2015, 295). Bolaño, then, uses certain tropes from the genre to expose institutions and the government's inherent corruption and ineptitude.

As well as the plot borrowing from the tropes of detective fiction, the text and its construction are also used as a critique of history and how we confront history. The majority of Bolaño's characters in Amulet are outsiders: foreigners, artists, transients, homosexuals and so on, which populate Auxilio's memory. They have a history but it is a history that will never make the annals of institutionalised history and its agenda. The crime novel becomes a vehicle for social change. "History, which is a simple whore, has no decisive moments but is a proliferation of instants, brief interludes that vie with one another in monstrousness" (Bolaño 2008, 794).

\section{7}

Conclusion

Thus, it is clear that Bolaño's Amulet can be seen and better understood by considering it as a work of historiographic metafiction that employs some of the tropes of the metaphysical detective genre. However, it is important not to lose sight of what Bolaño is trying to do by approaching his novel this way. History is investigated by way of its effect on the individual and how the writers of history attempt 'to write history by erasing the history of those it destroys' (Bogue 2010, 129). Bolaño seeks to reclaim this history through his novel and to keep the memory and significance alive. This is not done by offering an alternative version of the established facts. It is done by opening it up to interpretation which keeps the text alive and, by extension, the event and its consequences. So, although fiction may not 'rescue history from its confusions', it seems that 
the novel can be the perfect vehicle for "finding rhythms and symmetries [in history] that we simply don't encounter elsewhere" (DeLillo 2017, 64).

\section{References}

Auster, Paul. 2006. The New York Trilogy: City of Glass, Ghosts, The locked Room. New York: Penguin Books.

Block, Melissa, and Michele Norris. 2017. "Falling Man Maps Emotional Aftermath of Sept. 11: Interview with Don DeLillo". Npr.org. <https://www.npr.org/transcripts/ $11223451>$.

Bogue, Ronald. 2010. Deleuzian Fabulation and the Scars of History. Edinburgh: Edinburgh UP.

Bolaño, Roberto. 1993. The Skating Rink. London: Picador.

Bolaño, Roberto. 2007. The Savage Detectives. London: Picador.

Bolaño, Roberto. 2008. 2666. London: Picador.

Bolaño, Roberto. 2010. Amulet. London: Picador.

Bolaño, Roberto. 2012. Woes of the True Policeman. London: Picador.

Bolaño Roberto, et al. 20o9. Roberto Bolaño: The Last Interview \& Other Conversations. Melville House Publishing.

Borges, Jorge Luis. 1998a. "Death and the Compass". Collected Fictions. New York: Viking. Borges, Jorge Luis. 1998b. “The Garden of Forking Paths". Collected Fictions. New York: Viking.

Borges, Jorge Luis. 1998c. "Ibn Hakkan Al-Bokhari - Dead in his Labyrinth". Collected Fictions. New York: Viking.

Braham, Persephone. 2004. Crimes against the State, Crimes against Persons. Detective Fiction in Cuba and Mexico. Minneapolis: $U$ of Minnesota Press.

Deleuze, Gilles, and Felix Guattari. 1987. A Thousand Plateaus: Capitalism and Schizophrenia. London: University of Minnesota Press.

Eagleton, Terry. 1996. The Illusions of Postmodernism. Cornwell: Blackwell Publishing. Eco, Umberto. 2004. The Name of the Rose. London: Vintage Classics.

Guattari, Felix. 2010. Machinic Unconscious: Essays in Schitzoanalysis. Cambridge: the MIT Press.

Holquist, M. 1971. New Literary History: A journal of theory and interpretation. Charlottesville, VA.: University of Virginia.

Hutcheon, Linda. 1988. A Poetics of Postmodernism: History, Theory, Fiction. New York: Routledge.

Jameson, Fredric. 1991. Postmodernism, or, the Cultural Logic of Late Capitalism. Durham: Duke University Press. 
Lodge. David. 2015. The Modes of Modern Writing: Metaphor, Metonymy, and the Typology of Modern Literature. Chennai: Bloomsbury Revelations.

Long, Ryan. 2010. "Traumatic Time in Roberto Bolaño's Amuleto and the Archive of 1968." Bulletin of Latin American Research 29: 128-43.

Marinescu, Andreea. 2013. Testimonio in the Lettered City: Literature and Witnessing in Roberto Bolaño's Amuleto 42: 134-146.

Marostain, Monica. 2009. Roberto Bolaño: The Last Interview and Other Conversations. New York: Melville House Publishing.

Merivale, Patricia, and Susan Elizabeth Sweeney.1999. Detecting Texts: The Metaphysical Detective Story from Poe to Postmodernism. Philadelphia: U of Pennsylvania.

Newman, C. 1985. The Post-modern Aura: The Act of Fiction in an Age of Inflation. Evanston: Northwestern University Press.

Pastén, J Agustín. 2013. "Anatomy of the Detective Genre in Roberto Bolaño Poetry." Chasqui 42(1): 16-36.

Poe, Edgar Allan. 1966a. "The Murders in the Rue Morgue”. Complete Poems and Stories. New York: Garden City.

Poe, Edgar Allan. 1966b. “The Purloined Letter”. Complete Poems and Stories. New York: Garden City.

Poe, Edgar Allan. 1966c. "The Mystery of Marie Roget". Complete Poems and Stories. New York: Garden City.

Pynchon, Thomas. 1966. The Crying of Lot 49. Philadelphia: Lippincott.

Spanos, William. 1972. "The Detective and the Boundary." Boundary 2 1(1): 147-168. Duke University Press.

Žižek, Slavoj. 1992. Looking Awry: An Introduction to Jacques Lacan Through Popular Culture. London: MIT Press. 